\title{
Some expected impacts of the Common Fishery Policy on marine food webs
}

\author{
Kopp Dorothée ${ }^{1,{ }^{*}}$, Robert Marianne ${ }^{1}$, Chouvelon Tiphaine ${ }^{2,3}$, Méhault Sonia ${ }^{1}$
}

${ }^{1}$ Ifremer, Unité de Sciences et Technologies halieutiques, Laboratoire de Technologie et Biologie Halieutique, 8 rue François Toullec, F-56325 Lorient Cedex, France

2 Ifremer, Unité Biogéochimie et Écotoxicologie, Laboratoire de de Biogéochimie des Contaminants Métalliques, rue de l'île d'Yeu, B.P. 21105, F-44311 Nantes Cedex 03, France

${ }^{3}$ Littoral Environnement et Sociétés, UMR 7266 CNRS - Université La Rochelle, 2 rue Olympe de Gouges, F-17042 La Rochelle Cedex 01, France

* Corresponding author : Dorothée Kopp, email address : dorothee.kopp@ifremer.fr

\begin{abstract}
:
For the ecosystem approach to fisheries management, understanding population dynamics and ecosystem resilience in response to the landing obligation acted by the reform of the European Common Fishery Policy (CFP) is currently an important avenue of research. This study attempts to assess the impact of the new CFP on marine food webs. Total carbon and nitrogen loss induced by a discard ban were estimated for the ecosystem of the Bay of Biscay based on French At-Sea Observer data and carbon and nitrogen content of discarded fish. Changes in predator diets were estimated by comparing two Bayesian mixing models, one mimicking the current situation and the second the application of the new CFP (removing the discarded species that would be landed from the model). Results illustrate a substantial shift in predation effort toward remaining available prey. The impact of changes in diet on individual and population health and on ecosystem functioning are important issues that remain to be assessed. A sister study could be carry out in another ecoregion, at a finer spatial scale in order to compare impacts and ecosystem responses. European monitoring programs such as DC-MAP and the Marine Strategy Framework Directive (MSFD) would help us to gain an understanding of how the food web would reorganize itself.
\end{abstract}

\section{Highlights}

- Potential impacts of the new Common Fishery Policy were assessed in the Bay of Biscay. Carbon and nitrogen loss induced by the discard ban were determined. Changes in predator diets following the discard ban were estimated. Bayesian mixing models revealed substantial shift in predation effort. Removal of food web components would produce shifts in predator trophic niches.

Keywords : Fishery discards, Discard ban, Bay of Biscay, Organic input, Resource use 


\section{Introduction}

Fisheries discards, corresponding to animals caught but returned to the sea due to minimum allowable landing size, quota restriction or low commercial value of species, are estimated at about 7 million tons per year (Kelleher 2005). North East Atlantic fisheries are identified as the second largest source of total removals (Alverson et al. 1994; Kelleher 2005), with some fisheries, like Nephrops trawlers, reaching discard rates of up to $50 \%$ (Kelleher 2005). Several tools are already being used to reduce discards, such as gear modifications (Revill et al. 2006; Madsen et al. 2010), area closures (e.g. the plaice-box in Rijnsdorp et al. 1998), acoustic and optical detection (Breen et al. 2012) or local discard bans (Diamond and Beukers-Stewart 2011) and have proved to significantly reduce discards in fisheries where they were tested. Despite these measures, the European Union reformed the Common Fishery Policy (CFP) and approved the landing obligation, implying that discarding any individuals of species under quota will be prohibited (Official Journal of the European Union, December $28^{\text {th }}$ 2013).

It is well known that fishing activity is the most important major disturbance to marine ecosystems (Jennings and Kaiser 1998; Jackson et al. 2001). Among other changes, fishing modifies food web structure and stability by removing species from their environment (Pauly et al. 1998; Bascompte et al. 2005). However, some species have become quite dependent on fisheries activities by either feeding on dead or damaged fauna on the seabed (Kaiser and Spencer 1994; Groenewold and Fonds 2000), or feeding on discarded organisms (Olaso et al. 1998; Jenkins et al. 2004; Votier et al. 2013). Dead fishes that are not immediately eaten by predators but which fall on the seabed could also modify nutrient cycling processes through decomposition, and supply a significant proportion of the nutrients required for primary production (Bilby et al. 1996). Examples from aquatic ecosystems demonstrate that fish carcasses could provide up to $70 \%$ of a system's primary production (Finney et al. 2000). In the North Sea, estimation of food production from damaged organisms or dead fish reaching the bottom revealed that a single passage of a beam trawl produced $8-24 \%$ of the food requirements of local scavengers (Groenewold and Fonds 2000). So, in the same way that fishing 
perturbs the stability of trophic networks, the discard ban imposed in the reforms of the EU Common Fisheries Policy may have a significant impact on scavenger communities, as several population parameters such as reproductive success or growth are closely linked to food abundance and availability (Oro et al. 1996).

Research has also shown that some species survive the discarding process and that according to biological, environmental and technical parameters, survival could be substantial (Revill 2012). Following the implementation of the landing obligation, any individuals that would otherwise have survived the discarding process would no longer contribute to the stock, but to the overall fishing mortality.

In the context of an ecosystem approach to fisheries management, it is crucial to understand the impact of a discard ban on the food web. The present study is an attempt to assess the expected shortfalls of this fishing regulation in the Bay of Biscay (North-East Atlantic) in terms of inputs of organic matter for the ecosystem and predation reallocation to different prey species depending on the importance of the discard species for their diet. More precisely, stable isotopes of carbon and nitrogen, which are recognized as powerful tools for describing food web structure (Pinnegar and

Polunin 1999), and a Bayesian mixing model that makes it possible to characterize source contributions to predator diet (Parnell et al. 2010), were used to make inferences on relative resources used among four examples of predatory fishes in the Bay of Biscay.

\section{Methods}

\subsection{Sample collection}

All the species under quota in ICES division VIII were considered except saithe Pollachius virens, which was absent from the sampling area and for which no discards were observed in 2014 or 2015 (Table 1). The other under-quota species were: boarfish Caproidae (Capr), roundnose grenadier Coryphaenoides rupestris (Crup), anchovy Engraulis encrasicolus (Eenc), cod Gadus morhua (Gmor), 
megrims Lepidorhombus spp. (Lepi), anglerfish Lophidae (Loph), haddock Melanogrammus aeglefinus (Maeg), whiting Merlangius merlangus (Mmer), hake Merluccius merluccius (Merl), blue whiting Micromesistius poutassou (Mpou), ling Molva molva (Mmol), Norway lobster Nephrops norvegicus (Nnor), plaice Pleuronectes platessa (Ppla), pollack Pollachius pollachius (Ppol), skate and ray Rajiformes (Raji), mackerel Scomber scombrus (Ssco), sole Solea spp. (Sole) and horse mackerel Trachurus spp. (Trac). Specimens of all these species were collected in 2014 onboard commercial vessels in coastal or shelf areas. A total of 95 specimens were sampled. The size range of each species was selected under minimum landing sizes in the ICES VIII division.

Table 1 here

\subsection{Stable isotope analysis}

Stable isotopes of carbon and nitrogen are commonly used to examine consumer trophic ecology, providing a time-integrated measure of trophic position and energy sources. The basic rationale of the stable isotopes approach is that the isotopic composition of consumer tissues reflects that of their diet, which in turn depends on the relative proportions of prey species assimilated over a specific time period (De Niro and Epstein, 1978; Minagawa and Wada, 1984; Peterson and Fry, 1987). Nitrogen stable isotope ratios in consumers are useful for defining trophic positions of consumers (Post, 2002) and carbon isotope ratios are typically used to define diet compositions or sources of energy (De Niro and Epstein, 1978). From each individual, a small piece of muscle tissue was dissected and kept freeze-dried until further analysis. All samples were oven dried $\left(60^{\circ} \mathrm{C}\right.$ for $\left.48 \mathrm{~h}\right)$ and ground into a homogeneous powder using a mixer mill. Determination of $\delta^{15} \mathrm{~N}, \delta^{13} \mathrm{C}$ and $\%$ content of $\mathrm{C}$ and $\mathrm{N}$ were undertaken at the Stable Isotopes in Nature Laboratory (University of New Brunswick, Canada) using a Carlo Erba NC2500 Elemental Analyzer. Isotope ratios were reported in delta 
notation in accordance with international standards: Pee Dee belemnite carbonate for $\delta^{13} \mathrm{C}$ and atmospheric nitrogen for $\delta^{15} \mathrm{~N}$. Data were corrected using working standards (bass muscle, bovine liver, nicotinamide; SD $<0.2 \%$ for both $\delta^{13} \mathrm{C}$ and $\delta^{15} \mathrm{~N}$ ) that had been previously calibrated against the International Atomic Energy Agency (IAEA) standards.

\subsection{Data analysis}

\section{Carbon and nitrogen loss}

In order to estimate potential carbon and nitrogen loss for food webs, discard estimates for the main fisheries of the Bay of Biscay were obtained from the French At-Sea Observer Program for 2012 and 2013 (Cornou et al. 2013; 2015). The fleets concerned were bottom trawlers (targeting either fish or Nephrops), trawlers targeting small pelagic fish, netters, Danish seiners and long liners (Table 1).

The total carbon and nitrogen loss for the ecosystem were estimated as follows:

$$
C_{\text {loss }}=\sum_{i=1}^{19} \sum_{j=1}^{6} W_{i j} * C C_{i}
$$

and

$$
N_{\text {loss }}=\sum_{i=1}^{19} \sum_{j=1}^{6} W_{i j} * N C_{i}
$$

where $\mathrm{W}$ is the weight of discarded species $i$ in fleets $j$ and $\mathrm{CC}_{\mathrm{i}}$ and $\mathrm{NC}_{\mathrm{i}}$ are the carbon and nitrogen content of species $i$, respectively (Table 2 ).

[Table 2 here] 
In order to establish whether discarded fish species are potential prey for piscivorous organisms, their stable isotope values were compared with stable isotope values of predators from Chouvelon et al. (2012) in the Bay of Biscay.

First, trophic groups of discarded species were identified by hierarchical clustering analysis on $\delta^{15} \mathrm{~N}$ and $\delta^{13} \mathrm{C}$ values using Ward's minimum variance method (Ward 1963). This method is based on the linear model criterion of least squares and its objective is to define groups that minimize the withingroup sum of squares. Computation of within-group sums of squares is based on a Euclidean model. Given that sample size varied between taxa, but that the intention was to account for within-sample variation in isotopic ratios, hierarchical clustering was performed on a bootstrapped matrix of distances between species, which was computed as follows: since the minimum sample size was three, three individuals per species were sampled with replacement. The isotopic ratios of these samples were then used as coordinates to compute a Euclidian distance matrix between species after standardizing coordinates to 0 mean and unit variance. This procedure was repeated 500 times, and the resulting distance matrices were averaged to obtain the bootstrapped distance matrix on which clustering was performed. The number of resamplings was sufficient to stabilize the values of the bootstrapped distance matrix. After clustering, the optimal number of clusters was assessed by visual inspection of the resulting dendrogram and confirmed using graphs of the fusion level (Borcard et al., 2011).

Then the Bayesian mixing model SIAR (Stable Isotope Analysis in R) developed by Parnell et al. (2010) was used to determine the contribution of potential prey from the Bay of Biscay to a predator's diet. SIAR is a mixing model that is not constraint by the number of sources and takes into account the variability of input parameters like consumer and source isotopic signatures and trophic enrichment factor. Fractionation factors between resources and consumers were assumed to be $1 \pm 0.5$ for $\delta^{13} \mathrm{C}$ and $3.4 \pm 1$ for $\delta^{15} \mathrm{~N}$, values which fall within the range most often reported for consumers analyzed in terms of their muscle (Peterson and Fry, 1987; McCutchan et al., 2003; Sweeting et al., 2007a, b). 
The groups of discarded species identified by cluster analysis were used as potential groups of prey as well as other potential prey, from those listed in Chouvelon et al. (2012), namely flying crab Liocarcinus holsatus (Lhol), angular crab Goneplax rhomboides (Grho), harbor crab Liocarcinus depurator (Ldep), European pilchard Sardina pilchardus (Spil), bogue Boops boops (Bboo), red gurnard Chelidonichthys cuculus (Ccuc), poor cod Trisopterus minutus (Tmin), grey gurnard Eutrigla gurnardus (Egur) and greater weever Trachinus draco (Tdra), which were grouped using the same classification approach described above. Four predator fish species from the Bay of Biscay (Chouvelon et al. 2012) that had previously been identified as feeding on fish and crustaceans (Fishbase, 2014) were used as case study: ground shark Mustelus asterias (Mast), small-spotted catshark Scyliorhinus canicula (Scan), European seabass Dicentrarchus labrax (Dlab) and conger Conger conger (Ccon). Stable isotope data from the present study and from Chouvelon et al. (2012) were corrected for variations in baseline values using isotopic ratios of suspension-feeding bivalves from the Pectinidae family (Post 2002) to ensure consistency between the two datasets.

For each of the four predators, two models were run to assess the impact of the future discard ban on their diet. The first of these models described the current situation, where the presently discarded species, the ones concerned by the new CFP and species that will continue to be discarded (species not under quota), were available for predators. The second model simulated the application of the new CFP by removing from the model the discarded species that will be landed (species under quota).

All the statistical analysis and SIAR calculations were performed using $R \quad 3.1 .3$ software (R Development Core Team, 2015). 
3. Results

3.1. Carbon and nitrogen loss

Two fisheries in the Bay of Biscay are responsible for most of the discards. The highest quantity of discard for species under quota is observed for Nephrops bottom trawlers, with 2809 and 3352 tons of discards in 2012 and 2013, respectively, followed by bottom fish trawlers ( 2530 and 1909 tons in 2012 and 2013, respectively). Hake and Nephrops are the most discarded species (Table 1). The fleet that generates the least discards of species under quota is that of the longliners with 171 and 98 tons in 2012 and 2013, respectively.

Based on these discard estimates, considered in terms of tonnage and according to the carbon and nitrogen content of the discarded species under quota in this area (Table 2), the potential losses for food webs are about 3300 tons of carbon and 1100 tons of nitrogen per year in the Bay of Biscay.

\subsection{Discard contribution to predator diet}

Hierarchical clustering performed on $\delta^{13} \mathrm{C}$ and $\delta^{15} \mathrm{~N}$ values illustrated that species under quota discarded by the fisheries from the Bay of Biscay could be sub-divided into four trophic groups (Figure 1). Two groups of primary to secondary consumers could be distinguished: a benthic one, Group $1\left(\delta^{15} \mathrm{~N}=9.19 \pm 0.13 ; \delta^{13} \mathrm{C}=-16.46 \pm 0.13\right)$, represented by Nephrops; and another that was half composed of pelagic species (Group 2; $\delta^{15} \mathrm{~N}=10.65 \pm 0.13 ; \delta^{13} \mathrm{C}=-17.68 \pm 0.10$ ). Isotopic values allowed further discrimination of two groups of secondary to tertiary consumers: one mostly contained omnivorous fishes (Group $3 ; \delta^{15} \mathrm{~N}=12.27 \pm 0.15 ; \delta^{13} \mathrm{C}=-16.55 \pm 0.08$ ) and one formed by benthic species (Group 4; $\delta^{15} \mathrm{~N}=11.51 \pm 0.28 ; \delta^{13} \mathrm{C}=-15.51 \pm 0.16$ ). Species that are not subject to the landing obligation could be sub-divided into three trophic groups. Group 5 is similar to Group 3 and contains omnivorous fishes, Group 6 is similar to Group 2 and is composed of pelagic species, and Group 7 is made up Crustaceans (Figure 1). 
[Figure 1 here]

Prey contributions to upper consumer diets revealed by the first mixing model (current situation) showed that all the groups of preys composed by discarded organisms are consumed by predators (Group 1 to 4 on Figure 2). Ground shark (M. asterias) utilized Group 1 as its principal food source, with an average contribution of $21 \%$ (Figure 2). Group 2 provided $39 \%$ of the assimilated diet of small-spotted catshark (S. canicula) and contributed almost equally with Group 1 to the dietary requirements of seabass. Piscivorous top-predators from high trophic levels, such as European conger (C. conger) (Figure 1), depended mainly on Groups 3 and 5 (average contributions of $16 \%$ and $17 \%$, respectively). Among discards of species under quota, Group 4 makes the least contribution to predator diets (Figure 2). When groups composed by discarded organisms (second mixing model, white bars in Figure 2) were removed, the predation report was strongly indicated. Ground shark shifted to Group 7, composed of crabs (average contribution of 16\%). Group 6 became the group that contributed the most to seabass and small-spotted catshark diets $(50 \%$ and $64 \%$ of these diets, respectively). European conger allocated its predation effort across the three remaining groups.

[Figure 2 here]

\section{Discussion}

The global reduction of discards is an essential strategy for sustainable fishing, and discard bans are currently being implemented in Alaska, British Columbia, New Zealand, The Faroe Islands, Norway and Iceland (Condie et al. 2014). However, the effects on population, community and ecosystem functioning, whether beneficial or detrimental, direct or indirect, are still unclear. Direct positive 
impacts of the new CFP on fish stock status are closely linked to the ability to reduce undersized fish mortality through changes in fishing practice (including spatiotemporal allocation of effort and selectivity improvement) and catch quotas (Sarda et al. 2015). Nevertheless, on-board retention of discards with high survival probability would increase fishing mortality compared to the current situation.

Discarding is an old fisher's practice that has shaped marine food webs for decades. From a marine ecology dynamics perspective, sudden and drastic decrease of discarding practice may disturb the present equilibrium, as discards of species under quota represented more than $50 \%$ for the total discards of some fisheries (i.e. Nephrops trawlers in the Bay of Biscay; Cornou et al. 2015). The four examples provided in this study confirmed that discarded species are actually eaten by predators and illustrated that when removing some components of the food web, a shift occurs in the predator dietary niche.

Food webs are complex systems driven by nonlinear cascade effects and feedback loops. As a consequence, the predictions of population dynamics responses and ecosystem resilience to this new paradigm can be important and require dedicated data collection, analysis, simulations and modeling tools (Heath et al. 2014). Discards transfer organic material from the sea bottom and water column to the surface, changing its availability in the entire marine food web (Bluhm and Bechtel 2003). Several studies from around the world indicate that a fraction of discards are taken by sea birds at the sea surface (Bicknell et al. 2013; Sotillo et al. 2014), sinking material can be consumed in the water column by sharks or marine mammals (Hill and Wassenberg 1990; 2000) and carcass and carrion by seafloor opportunists and scavengers such as fish, crustaceans and echinoderms (Ramsay et al. 1997; Groenewold and Fonds 2000; Jenkins et al. 2004). Some attempts have been made to estimate the contribution of discards to the species' diets using stomach content analysis (Olaso et al. 1998; 2002) and video devices (Ramsay et al. 1997; Bozzano and Sarda 2002; Votier et al. 2013; Garcia-Tarrason et al. 2015). At a community level, another important need is to quantify the 
potential losses for entire food webs and to identify the functional groups that would potentially be affected. In this paper, we combine stable isotope data, mixing models and discard estimates to propose (i) an initial evaluation of potential losses for food webs in terms of carbon and nitrogen per year in the Bay of Biscay, (ii) a classification of discards in terms of groups of prey, (iii) a quantification of discard consumption by four top predators and (iv) an illustration of what could be the reallocation of predation effort to other potential prey under the landing obligation scenario. The Bayesian mixing models used in this study do not take into account prey abundance or the influence of prey quality (energy content), which prevents us from assessing the impact of this shift in diet on individual and population health. To move forward, these results could then be used to simulate more holistic scenarios using ecosystem modeling such as Ecopath. Indeed, input parameters of such models require biomass estimates in $\mathrm{kg} \mathrm{C} \mathrm{km}^{-2}$. The present study provides recent discard estimates of $33 \mathrm{~kg} \mathrm{C} \mathrm{km}^{-2}$ for under-quota discarded species, updating the value used in Lassalle et al. (2012) for the discard component.

The results presented need to be interpreted in terms of order of magnitude, knowing that discard estimates are fairly tentative because they are variable in space and variable across year due to stock dynamics and managements constraints. Moreover, this study is based on French discard estimates only and does not take into account discards for other European fleets that operate in the area. Several accounts in the literature also indicate that diet preferences and predator-prey interactions are highly variable in space and time depending on substrate, habitat and local population densities (e.g. Ramsay et al. 1997). The new CFP will push fisherman to adopt efficient selectivity devices, which will probably drastically decrease the quantity of discarded fish in the next few years, but "zero discard" is difficult to achieve in a mixed fisheries context. It is noteworthy that the food supply made up of discards would not stop completely because the new EU legislation is only applicable for the management of species under quota and requires fisher's compliance and efficient control. Additionally, the new CFP is likely to include some flexibility that will allow fishermen to continue 
discarding species under particular conditions. In this context, the landing obligation scenario we tested appears to be an extreme situation.

The data required to perform this study are easy to collect (muscle samples, food web structure, discard estimates) and data analyses are based on well-established methods (carbon and nitrogen contents, stable isotope analysis and mixing models). Such work could therefore be implemented in other marine ecoregions in order to quantify and compare potential losses among ecosystems and to assess the impact on boundary and widely distributed stocks.

Monitoring discard quantities, population status and health metrics (such as fitness) of individual fish could help us to understand how ecosystems will respond to this new disturbance in the next decade. In this context, the study presented here provides a valid reference point for the Bay of Biscay. Finally, scavenging on carcasses of top predators can influence the isotopic signature of species that feed on and increase estimates of their trophic level. Then, an important reduction of waste supply is likely to modify the isotope signatures of species. As such, we recommend regular analysis of stable isotope ratios and stomach contents as this could also help to monitor how the food web will reorganize itself after the discard ban is put into application. Data collection and monitoring conducted as part of the Data Compilation framework (DC-MAP) and Marine Strategy Framework Directive (MSFD, EC 2008) should make it possible to carry out this kind of study in coming years.

\section{Acknowledgments}

This work was part of the ENSURE project supported by France Filière Pêche and the Direction des Pêches Marines et de l'Aquaculture. The authors thank Camille Vogel and Fabien Morandeau for their help onboard the fishing vessel "Déesses de l'Océan", and Paco Bustamante (LIENSs laboratory) for 
his help using some raw isotopic data analyzed by the "Plateforme isotopique" from the LIENSs laboratory during the $\mathrm{PhD}$ of $\mathrm{T}$. Chouvelon (funding from the "Conseil Régional de Poitou Charentes").

\section{References}

Alverson DL, Freeberg MH, Murawski SA, Pope JG (1994). A global assessment of fisheries bycatch and discards. Fisheries technical paper FAO no. 339

Bascompte J, Melián CJ, Sala E (2005). Interaction strength combinations and the overfishing of a marine food web. Proceedings of the National Academy of Sciences of the USA, 102, 54435447

Bicknell AWJ, Oro D, Camphuysen K, Votier SC (2013). Potential consequences of discard reform for seabird communities. Journal of Applied Ecology, 50, 649-658

Bilby RE, Fransen BR, Bisson PA (1996). Incorporation of nitrogen and carbon from spawning coho salmon into the trophic system of small streams: evidence from stable isotopes. Canadian Journal of Fisheries and Aquatic Sciences, 53, 164-173

Bluhm BA, Bechtel PJ (2003). The potential fate and effects of seafood processing wastes dumped at sea: A review. In: Advances in seafood byproducts (PJ Bechtel ed.). Alaska Sea Grant College Program, University of Alaska, Fairbanks, AK, pp 121-140

Borcard D, Gillet F, Legendre P, (2011). Numerical Ecology with R. UseR! Series. Springer, New York, USA.

Bozzano A, Sarda F (2002). Fishery discard consumption rate and scavenging activity in the northwestern Mediterranean Sea. ICES Journal of Marine Science, 59, 15-28 
Breen M, Isaksen B, Ona E, Pedersen, AO, Pedersen G, Saltskår J, Svardal, B, Tenningen M, Thomas PJ, Totland B, Ø vredal JT, Vold A (2012). A review of possible mitigation measures for reducing mortality caused by slipping from purse-seine fisheries. ICES CM 2012/C:12

Chouvelon T, Spitz J, Caurant F, Méndez-Fernandez P, Chappuis A, Laugier F, Le Goff E, Bustamante P (2012). Revisiting the use of $\delta 15 \mathrm{~N}$ in meso-scale studies of marine food webs by considering spatio-temporal variations in stable isotopic signatures. The case of an open ecosystem: the Bay of Biscay (North-East Atlantic). Progress in Oceanography, 101, 95-102

Condie HM, Grant A, Catchpole TL (2014). Incentivising selective fishing under a policy to ban discards; lessons from European and global fisheries. Marine Policy, 45, 287-292

Cornou A-S, Diméet J, Tetard A, Gaudou O, Dube B, Fauconnet L, Rochet M-J (2013). Observations à bord des navires de pêche professionnelle. Bilan de l'échantillonnage 2012. http://dx.doi.org/10.13155/27787

Cornou A-S, Diméet J, Tetard A, Gaudou O, Quinio-Scavinner M, Fauconnet L, Dube B, Rochet M-J (2015). Observations à bord des navires de pêche professionnelle. Bilan de l'échantillonnage 2013. http://dx.doi.org/10.13155/35856

De Niro MJ, Epstein S (1978). Influence of diet on distribution of carbon isotopes in animals. Geochim. Cosmochim. Acta, 42, 495-506

Diamond B, Beukers-Stewart BD (2011). Fisheries discards in the North Sea: Waste of resources or a necessary evil? Reviews in Fisheries Science, 19, 231-245

Finney BP, Gregory-Eaves I, Sweetman J, Douglas MSV, Smol JP (2000). Impacts of climatic change and fishing on Pacific salmon abundance over the past 300 years. Science, 290, 795-799

Fishbase (2014). World Wide Web electronic publication, Froese R. and D. Pauly Editors. www.fishbase.org, version (11/2014) 
Garcia-Tarrason M, Becares J, Bateman S, Arcos JM, Jover L, Sanpera C (2015). Sex-specific foraging behavior in response to fishing activities in a threatened seabird. Ecology and Evolution, 5, $2348-2358$

Groenewold S, Fonds M (2000). Effects on benthic scavengers of discards and damaged benthos produced by the beam-trawl fishery in the southern North Sea. ICES Journal of Marine Science, $57,1395-1406$

Heath MR, Cook RM, Cameron Al, Morris DJ, Speirs DC (2014). Cascading ecological effects of eliminating fishery discards. Nature Communications, 5, 3893

Hill BJ, Wassenberg TJ (1990). Fate of discards from prawn trawlers in Torres Strait. Australian Journal of Marine and Freshwater Research, 41, 53-64

Hill BJ, Wassenberg TJ (2000). The probable fate of discards from prawn trawlers fishing near coral reefs. A study in the northern Great Barrier Reef, Australia. Fisheries Research, 48, 277-286

Jackson JBC, Kirby MX, Berger WH, Bjorndal KA, Botsford LW, Bourque BJ, Bradbury RH, Cooke R, Erlandson J, Estes JA, Hughes TP, Kidwell S, Lange CB, Lenihan HS, Pandolfi JM, Peterson CH, Steneck RS, Tegner MJ, Warner RR (2001). Historical overfishing and the recent collapse of coastal ecosystems. Science, 293, 629-637

Jenkins SR, Mullen C, Brand AR (2004). Predator and scavenger aggregation to discarded by-catch from dredge fisheries: importance of damage level. Journal of Sea Research, 51, 69-76

Jennings S, Kaiser MJ (1998). The effects of fishing on marine ecosystems. Advances in Marine Biology, 34, 201-212

Kaiser MJ, Spencer BE (1994). Fish scavenging behavior in recently trawled areas. Marine Ecology Progress Series, 112, 41-49 
Kelleher K (2005). Discards in the world's marine fisheries. An update, fisheries technical paper. FAO no. 470

Lassalle G, Gascuel D, Le loc'h F, Lobry J, Pierce GJ, Ridoux V, Santos MB, Spitz J, Niquil N (2012). An ecosystem approach for the assessment of fisheries impacts on marine top predators: the Bay of Biscay case study. ICES Journal of Marine Science, 69, 925-938

Madsen N, Frandsen RP, Holst R, Krag LA (2010). Development of new concepts for escape windows to minimize cod catches in Norway lobster fisheries. Fisheries Research, 103, 25-29

McCutchan JH, Lewis Jr WM, Kendall C, McGrath CC (2003). Variation in trophic shift for stable isotope ratios of carbon, nitrogen, and sulfur. Oikos, 102, 378-390

Minagawa $\mathrm{M}$, Wada $\mathrm{E}$, (1984). Stepwise enrichment of ${ }_{15} \mathrm{~N}$ along food chains: further evidence and the relation between $15 \mathrm{~N}$ and animal age. Geochim. Cosmochim. Acta, 48, 1135-1140

Olaso I, Velasco F, Pérez N (1998). Importance of discarded blue whiting (Micromesistius poutassou) in the diet of lesser spotted dogfish (Scyliorhinus canicula) in the Cantabrian Sea. ICES Journal of Marine Science, 55, 331-341

Olaso I, Sánchez F, Rodríguez-Cabello C, Velasco F (2002). The feeding behavior of some demersal fish species in response to artificial discarding. Scientia marina, 66, 301-311

Oro D, Jover L, Ruiz X (1996). Influence of trawling activity on the breeding ecology of a threatened seabird, Audouin's gull Larus audouinii. Marine Ecology Progress Series, 139, 19-29.

Parnell AC, Inger R, Bearhop S, Jackson A (2010). Source partitioning using stable isotopes: coping with too much variation. PloS ONE, 5, e9672

Pauly D, Christensen V, Dalsgaard J, Froese R, Torres Jr F (1998). Fishing down marine food webs. Science, $279,860-863$ 
Peterson BJ, Fry B (1987). Stable isotopes in ecosystem studies. Annual review of Ecology and systematics $18,293-320$

Pinnegar JK, Polunin NVC (1999). Differential fractionation of delta C-13 and delta N-15 among fish tissues: implications for the study of trophic interactions. Functional Ecology, 13, 225-231

Post DM, (2002). Using stable isotopes to estimate trophic position: Models, methods, and assumptions. Ecology, 83, 703-718

R Development Core Team (2015). R: A Language and Environment for Statistical Computing. R Foundation for Statistical Computing, Vienna, Austria, ISBN 3-900051-07-0. http://www.Rproject.org/.

Ramsay K, Kaiser MJ, Moore PG Hughes RN (1997). Consumption of fisheries discards by benthic scavengers: utilization of energy subsidies in different marine habitats. Journal of Animal Ecology, 66, 884-896

Revill A (2012). Survival of discarded fish. A rapid review of studies on discard survival rates. DG MARE A2. Request For Services Commitment No. S12.615631

Revill A, Dunlin G, Holst R (2006). Selective properties of the cutaway trawl and several other commercial trawls used in the Farne Deeps North Sea Nephrops fishery. Fisheries Research, $81,268-275$

Rijnsdorp AD, Buys AM, Storbeck F, Visser EG (1998). Micro-scale distribution of beam trawl effort in the southern North Sea between 1993 and 1996 in relation to the trawling frequency of the sea bed and the impact on benthic organisms. ICES Journal of Marine Science, 55, 403-419

Sarda F, Coll M, Heymans JJ, Stergiou KI, (2015). Overlooked impacts and challenges of the new European discard ban. Fish and Fisheries, 16, 175-180 
Sotillo A, Depestele J, Courtens W, Vincx M, Stienen EWM (2014). Consumption of discards by Herring Gulls Larus argentatus and Lesser Black-backed Gulls Larus fuscus off the Belgian coast in the breeding season. Ardea, 102, 195-205

Sweeting CJ, Barry JT, Barnes C Polunin NVC, Jennings S (2007a). Effects of body size and environment on diet-tissue $815 \mathrm{~N}$ fractionation in fishes. J Exp Mar Bio Ecol, 340, 1-10

Sweeting CJ, Barry JT, Polunin NVC, Jennings S (2007b). Effects of body size and environment on diettissue $\delta 13 C$ fractionation in fishes. J Exp Mar Bio Ecol, 352, 165-176

Votier SC, Bicknell A, Cox SL, Scales KL, Patrick SC (2013). A bird's eye view of discard reformes: birdborne cameras reveal seabird/fishery interactions. Plos One. 8, e57376

Ward Jr JH, (1963). Hierarchical grouping to optimize an objective function. Journal of the American Statistical Association, 58, 236-244. 
Table 1. Estimates of discard biomass (in tons) per species under quota and per fishery in 2012 and 2013. Confidence intervals are available in Cornou et al. (2013; 2015).

Table 2. Mean $\delta 13 \mathrm{C}, \delta 15 \mathrm{~N}$, carbon and nitrogen content of species under quota in the Bay of Biscay $( \pm S D)$.

Figure 1. Mean $\delta^{15} \mathrm{~N}$ and $\delta^{13} \mathrm{C}$ values for the discarded species under quota in the ICES VIII division (

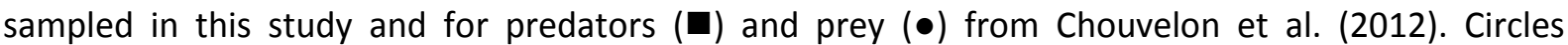
correspond to the results of hierarchical cluster analysis. Abbreviations are defined in the Methods section

Figure 2. Dietary composition (\%) of four predators, produced by the SIAR model using isotope values from several potential preys including discarded organisms (first model-current situation, in grey) and without discarded organisms following the new CFP implementation (second model-new CFP, in white). Boxes show $95 \%, 75 \%$ and $50 \%$ confidence intervals 
Table 1

\begin{tabular}{|c|c|c|c|c|c|c|c|c|c|c|c|c|c|c|}
\hline \multirow[b]{2}{*}{ Species } & \multicolumn{7}{|c|}{2012} & \multicolumn{7}{|c|}{2013} \\
\hline & $\begin{array}{c}\text { Fish bottom } \\
\text { trawl }\end{array}$ & $\begin{array}{c}\text { Nephrops } \\
\text { bottom trawl }\end{array}$ & $\begin{array}{c}\text { Small pelagic } \\
\text { trawl }\end{array}$ & Net $<15 \mathrm{~m}$ & Net $>15 m$ & Longline & Danish seine & $\begin{array}{c}\text { Fish bottom } \\
\text { trawl }\end{array}$ & $\begin{array}{c}\text { Nephrops } \\
\text { bottom trawl }\end{array}$ & $\begin{array}{c}\text { Small pelagic } \\
\text { trawl }\end{array}$ & Net $<15 \mathrm{~m}$ & Net $>15 m$ & Longline & Danish seine \\
\hline Caproidae & 161 & 9 & 0 & 0 & 0 & 0 & 0 & 306 & 11 & 0 & 0 & 0 & 0 & 0 \\
\hline Coryphaenoides rupestris & 9 & 0 & 0 & 0 & 0 & 0 & 0 & 0 & 0 & 0 & 0 & 0 & 0 & 0 \\
\hline Engraulis encrasicolus & 5 & 0 & 215 & 0 & 0 & 0 & 0 & 0 & 0 & 207 & 0 & 0 & 0 & 0 \\
\hline Gadus morhua & 0 & 0 & 0 & 11 & 0 & 0 & 0 & 0 & 0 & 0 & 0 & 0 & 0 & 0 \\
\hline Lepidorhombus spp. & 50 & 36 & 0 & 0 & 0 & 0 & 0 & 74 & 77 & 0 & 0 & 2 & 0 & 1 \\
\hline Lophidae & 225 & 78 & 0 & 31 & 13 & 0 & 1 & 351 & 59 & 0 & 7 & 3 & 0 & 2 \\
\hline Melanogrammus aeglefinus & 25 & 0 & 0 & 0 & 2 & 0 & 0 & 39 & 0 & 0 & 0 & 11 & 0 & 0 \\
\hline Merlangius merlangus & 31 & 37 & 1 & 97 & 71 & 9 & 123 & 116 & 26 & 2 & 123 & 15 & 9 & 16 \\
\hline Merluccius merluccius & 174 & 1174 & 53 & 29 & 414 & 56 & 13 & 216 & 1330 & 35 & 101 & 575 & 2 & 29 \\
\hline Micromesistius poutassou & 14 & 78 & 8 & 0 & 0 & 41 & 0 & 43 & 377 & 0 & 2 & 13 & 22 & 3 \\
\hline Molva molva & 0 & 0 & 0 & 3 & 4 & 0 & 0 & 0 & 0 & 0 & 2 & 1 & 0 & 0 \\
\hline Nephrops norvegicus & 2 & 1029 & 0 & 0 & 0 & 0 & 0 & 12 & 1386 & 0 & 0 & 0 & 0 & 0 \\
\hline Pleuronectes platessa & 2 & 0 & 0 & 0 & 0 & 0 & 0 & 2 & 3 & 0 & 6 & 0 & 0 & 4 \\
\hline Pollachius pollachius & 0 & 0 & 0 & 17 & 4 & 1 & 0 & 0 & 0 & 0 & 19 & 14 & 4 & 0 \\
\hline Pollachius virens & 0 & 0 & 0 & 0 & 0 & 0 & 0 & 0 & 0 & 0 & 0 & 0 & 0 & 0 \\
\hline Rajiformes & 246 & 0 & 0 & 45 & 22 & 58 & 0 & 552 & 0 & 0 & 196 & 7 & 59 & 0 \\
\hline Scomber scombrus & 1165 & 186 & 43 & 68 & 106 & 6 & 54 & 40 & 14 & 203 & 35 & 9 & 1 & 53 \\
\hline Solea spp. & 30 & 19 & 0 & 17 & 6 & 0 & 0 & 12 & 4 & 0 & 11 & 2 & 0 & 1 \\
\hline Trachurus spp. & 391 & 165 & 38 & 60 & 29 & 0 & 149 & 144 & 68 & 84 & 19 & 0 & 0 & 97 \\
\hline
\end{tabular}


Table 2

\begin{tabular}{|l|c|c|c|c|}
\hline Species & $\boldsymbol{\delta}^{13 \mathrm{C}}(\%) \pm \mathrm{SD}$ & $\boldsymbol{\delta}^{15} \mathrm{~N}(\%) \pm \mathrm{SD}$ & Carbon (\%) & Nitrogen (\%) \\
\hline Caproidae & $-18.2 \pm 0.1$ & $10.7 \pm 0.2$ & $48.5 \pm 0.4$ & $14.9 \pm 0.2$ \\
\hline Coryphaenoides rupestris & $-17.8 \pm 0.3$ & $9.9 \pm 0.1$ & $46.9 \pm 1.2$ & $15.4 \pm 0.4$ \\
\hline Engraulis encrasicolus & $-16.9 \pm 0.1$ & $11.8 \pm 0.2$ & $47.3 \pm 0.6$ & $15.3 \pm 0.1$ \\
\hline Gadus morhua & $-16.2 \pm 0.1$ & $12.9 \pm 0.2$ & $47.0 \pm 0.8$ & $15.6 \pm 0.2$ \\
\hline Lepidorhombus spp. & $-17.3 \pm 0.3$ & $10.6 \pm 0.1$ & $47.4 \pm 0.4$ & $15.5 \pm 0.1$ \\
\hline Lophidae & $-17.1 \pm 0.2$ & $11.3 \pm 0.5$ & $45.9 \pm 0.5$ & $15.1 \pm 0.1$ \\
\hline Melanogrammus aeglefinus & $-16.6 \pm 0.2$ & $11.7 \pm 0.1$ & $47.6 \pm 0.5$ & $15.5 \pm 0.1$ \\
\hline Merlangius merlangus & $-16.5 \pm 0.1$ & $12.1 \pm 0.4$ & $44.2 \pm 0.4$ & $15.2 \pm 0.1$ \\
\hline Merluccius merluccius & $-17.2 \pm 0.1$ & $10.7 \pm 0.2$ & $44.4 \pm 0.3$ & $15.1 \pm 0.1$ \\
\hline Micromesistius poutassou & $-18.0 \pm 0.2$ & $10.2 \pm 0.4$ & $49.1 \pm 0.3$ & $15.1 \pm 0.1$ \\
\hline Molva molva & -16.6 & 12.6 & 48.5 & 15.9 \\
\hline Nephrops norvegicus & $-16.5 \pm 0.1$ & $9.2 \pm 0.1$ & $44.5 \pm 0.3$ & $14.7 \pm 0.1$ \\
\hline Pleuronectes platessa & $-15.6 \pm 0.4$ & $10.9 \pm 0.4$ & $45.1 \pm 0.1$ & $14.9 \pm 0.1$ \\
\hline Pollachius pollachius & $-16.4 \pm 0.2$ & $13.1 \pm 0.1$ & $46.8 \pm 0.5$ & $15.6 \pm 0.2$ \\
\hline Rajiformes & $-15.3 \pm 0.3$ & $11.3 \pm 0.4$ & $43.4 \pm 0.7$ & $17.6 \pm 0.2$ \\
\hline Scomber scombrus & $-18.1 \pm 0.5$ & $11.0 \pm 0.2$ & $49.2 \pm 2.1$ & $14.0 \pm 0.8$ \\
\hline Solea spp. & $-15.6 \pm 0.1$ & $12.3 \pm 0.5$ & $44.5 \pm 0.4$ & $15.2 \pm 0.1$ \\
\hline Trachurus spp. & $-17.3 \pm 0.3$ & $10.9 \pm 0.3$ & $47.1 \pm 0.7$ & $14.8 \pm 0.2$ \\
\hline
\end{tabular}




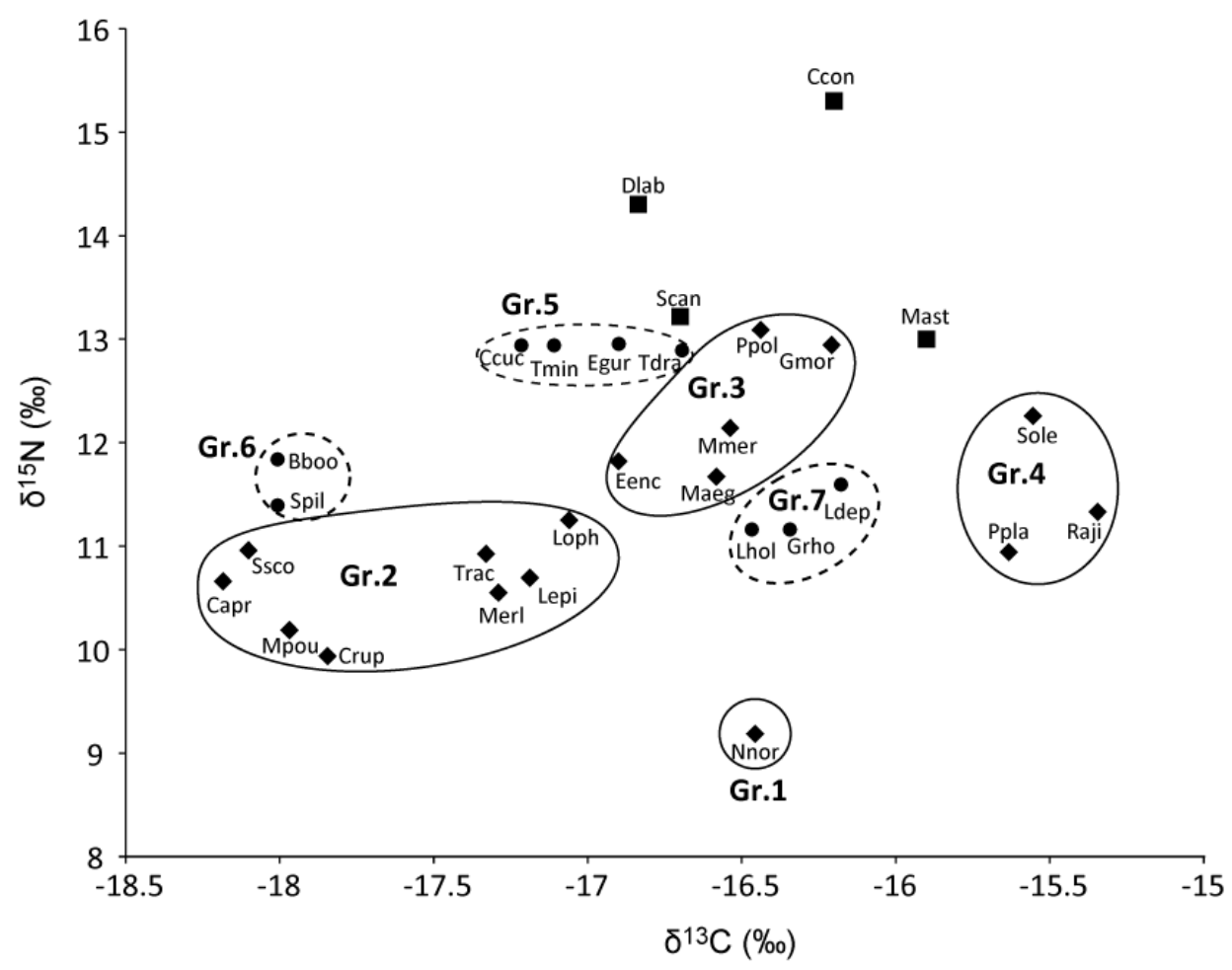

Figure 1 


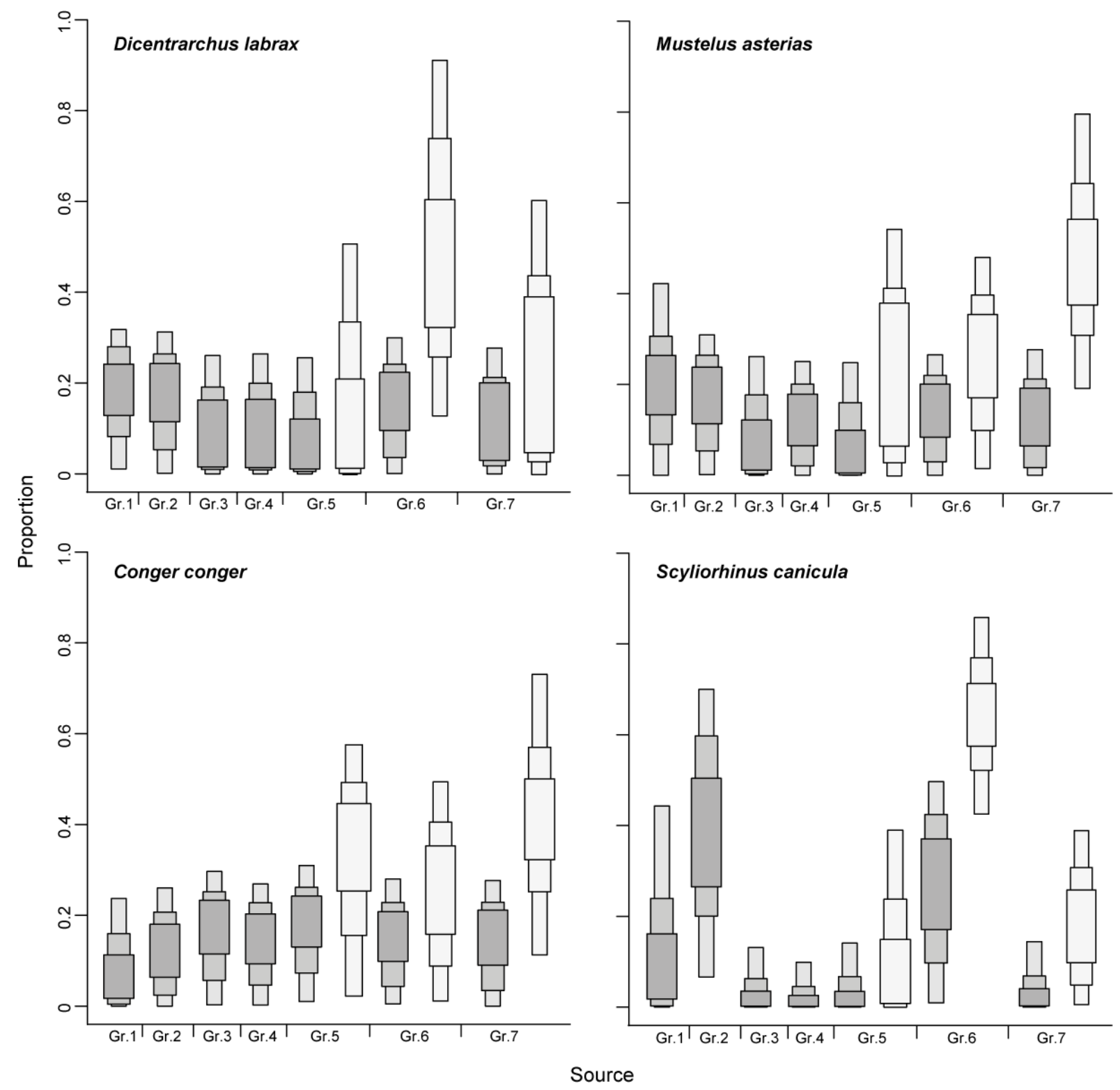

Figure 2 